\title{
細胞外マトリックスプロテアーゼと癌の転移
}

\section{癌細胞の組織への浸潤のために基底膜, 結合組織を破壊}

1 個の細胞の突然变異によって生じた癌細胞は, さら に遺伝子上の变異を伴いながら分裂を繰り返し，異質で 大きな細胞集団となる．これらの細胞のうちとくに運動 性に富む一部の細胞は原発巣から離脱し, 正常組織に移 動（浸潤）してゆき，そこで転移巣を形成する。浸潤・ 転移性は無限増殖性ととも癌細胞がもつ最も重要な性 質の一つである、言うまでもなく，転移は現代の癌の治 療に拈ける最も切実な問題であり，その有効な対策を得 るためには，まずそのメカニズムが解明されなければな らない。

癌の転移は, (1)転移細胞が原発巣から離脱し, 正常組 織に浸潤し，血管やリンパ管に侵入する過程，(2)血液や リンパ液を介して体内を移動する過程, (3)血管壁やリン パ管壁に付着する過程 (着床)，(4)血管やリンパ管から 外に移動する過程，(5)増殖して転移巣を形成する過程， などに大きく分割して考觉ることができる，これらの素 過程のなかでとくに重要と思われるのは(1)と(4)の浸潤過 程であり，転移全体の律速段階となっている.

生体組織は多数の細胞とその間を埋める 細胞間物質 （細胞外マトリックス extracellular matrix; 以下 ECM 之略す）から成り立っている. 代表的な ECM である通 常の結合組織は, 主に線維芽細胞之, それが分泌する間 質型（I～且型）コラーゲン，エラスチンなどの線維性 構造蛋白質, フィブロネクチン，ラミニンなどの細胞 接着性糖蛋白質, および複合多糖などから形成されて いる. 一方, 多くの上皮細胞や血管内皮細胞は基底膜 (basement membrane) と呼ばれる一層の膜の上に配列 して赫り,この膜によって下層の結合組織から完全に分 離されている. 基底膜は上皮細胞や内皮細胞などによっ て合成されたN型コラーゲン，ラミニン，プロテオグリ カンなどから形成された緻密な膜で, 分子量 4 万程度以 上の分子はこの膜を通過することができない，したがの て, 上皮組織に発生した癌細胞が正常組織に浸潤し, 毛 細血管やリンパ管に侵入するためには，プロテアーゼや ヘパラナーゼなどの加水分解酵素の作用によって基底膜
や結合組織が局部的汇破壊されなければならない(1).

最近, Goldberg や他のいくつかのグループの研究に より，ECM 蛋白質の破壊において中心的な役割を果た すと考兄られる 4 種類の分泌性メタロプロテアーゼ（間 質コラゲナーゼ， $\mathbb{N}$ 型コラゲナーゼ，ストロムリシン， マトリン) の性質が明らかにされた(2)。これらのらち， 間質コラゲナーゼは従来から知られている動物性コラゲ ナーゼで，I～正型の間質コラーゲンを構成する 3 本鎖 のペプチドを 1 個所の部位で特異的に切断する. Liotta のグループは, 転移性の高い細胞添ど基底膜コラーゲン (N型コラーゲン) を分解する酵素 (N 型コラゲナーゼ) を多量に分泌することを見いだした。彼らは，癌細胞の 基底膜への接着と浸潤が癌の転移にとってとくに重要と 考えており，転移細胞はまず自己の細胞表面に存在する ラミニンレセプターを介して基底膜のラミニンに結合 し，その後自らが分泌するN型コラゲナーゼによって 基底膜を破壞し，浸潤するというモデルを提唱してい る(3). 最近， 2 種のN型コラゲナーゼの全構造が決定さ れた(2). これらの酵素は従来ゼラチナーゼとして知られ ていた酵素で， $\mathrm{N}$ 型コラーゲンと変性コラーゲン（ゼラ チン)を強く分解するが，間質コラーゲンを分解しない，

ストロムリシン (stromelysin) は最初, 線維芽細胞が分 泌するプロテオグリカン分解酵素として見いだされた酵 素で, 主としてフィブロネクチン, ラミニン, プロテオグ リカンなどの ECM 蛋白質を分解する. 筆者らは, 正常 ラット由来の肝細胞株 BRL をラウス肉腫ウイルスで形 質転換すると，細胞表面に多量に存在したフィブロネク チンが泳㜔全に消失するとともに，括そらくその一つ の原因として, 得られた形質転換細胞 RSV-BRLがフ、 ブロネクチン分解性のメタロプロテフーゼを多量に分泌

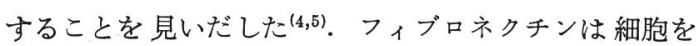
種々の基質に結合させる強力な接着蛋白質であることか ら，その消失は形質転換細胞に未沙る接着性の低下や運 動性の増大と関係すると思われる。一方, Matrisian ら ${ }^{(6)}$ は, ラットの線維芽細胞に括いて数種の癌遺伝子や表皮 
増殖因子 (EGF) によって誘導される mRNA を見つけ, それがコードする蛋白質をトランシン（transin）と名づ けた. その後, ヒトのストロムリシンの構造が決定され, トランシンとストロムリシンが高いホモロジーを有する ことが明らかになった．筆者らは，RSV-BRL 細胞が分 泌するフィブロネクチン分解酵素を単離してその部分ア ミノ酸配列を分析した結果，トランシンの配列とほぼ一 致することを明らかにした(7). したがって, 別々に発見 されたこれら 3 種の蛋白質は同一物質と考学られる.

最近, 筆者らは, 基質含有ゲル上での SDS 電気泳動 法 (zymography) を用いて 16 種類のヒト培養癌細胞が 分泌するプロテアーゼの分子種を分析した. その結果, 13 種の癌細胞が $\mathrm{Mr} 64 \mathrm{k}$ の $\mathrm{N}$ 型コラゲナーゼ, 6 種が $\mathrm{Mr} 90 \mathrm{k}$ のN型コラゲナーゼ，また 4 種がストロムりシ ン様のメタロプロテアーゼを分泌した. $64 \mathrm{k}$ のN型コラ ゲナーゼはかなり普遍的に分泌されるが, 正常線維芽細 胞もこの酵素を分泌することがわかった. さらに，ヒト 直腸癌細胞 CaR-1 細胞が他の細胞には見られない, $\mathrm{Mr}$ $29 \mathrm{k}$ のメタロプロテアーゼを分泌することを見いだし た．筆者らはこの酵素をマトリン（matrin）と名づけ， 単離して性質を調べた ${ }^{(8)}$. マトリンはストロムリシンと 同様に，広い基質特異性を有し，フィブロネクチン, ラ ミニン, $\mathrm{N}$ 型コラーゲンを強く分解した. マトリンの構 造解析の結果から, この酵素は, トランシン cDNA に ハイブリダイズする, ヒト癌細胞由来の mRNA の構造 解析からその存在が予知されていた仮想のメタロプロテ アーゼ pump-1 (putative metallo-proteinase-1) ${ }^{(9)}$ と同 一の酵素と考えられた.

以上のように, 癌細胞による ECM 破壊において主役 を演じると考えられるメタロプロテアーゼ・ファミリー のメンバーが相次いで明らかにされてきた、しかし，筆 者らの予備的な実験では, 浸潤性の高い癌細胞はこれら のプロテアーゼを多量に分泌する傾向にあるが，浸潤性 とプロテアーゼの分泌量とが必ずしも相関するわけでは ない.これは, すべてのメタロプロテアーゼは不活性な 前駆体として分必されており，それらが作用するために はまず活性化されなければならないこと, また多くの細 胞はこれらのメタロプロテアーゼの共通の阻害物質を同 時に分泌することと関係すると思われる. 現在, これら
のプロテアーゼの活性化は, まず多くの癌細胞が分泌す るプラスミノーゲン・アクチベーター（PA）が組織中 のプラスミノーゲンを限定分解してプラスミンに変換 し，このプラスミンがメタロプロテアーゼ前駆体を限定 分解して活性化させると考えられている. PA もプラス ミンもセリンプロテアーゼの一種であるが, 後者は前者 に比べて広い基質特異性を有して和り，ECM の直接的 な破壊も行なっている可能性がある. 一方, 多くの場 合, $\mathrm{N}$ 型ュラゲナーゼは 2 種のメタロプロテアーゼ阻害 物質 (TIMP， TIMP-2) のいずれかと不活性な複合体 を形成して分泌されることが明らかになってきた ${ }^{(2,10)}$. したがって, 癌細胞による ECM の破壊は, プロテアー ゼ, 活性化因子, 阻害物質の 3 者の相互作用の結果起こ ると考えられる. 詳細な分子機作の解明のためにはさら に今後の研究を待たなければならない.

\section{以上, 本稿ではとくに癌の浸潤に拈けるプロテアーゼ} の作用を考察したが，ECM の破壊はこの他にも，組織 の損傷と再生, 個体発生過程における細胞の移動, 血管 新生，炎症反応に拈ける白血球の遊走などにおいても見 られる. これらの現象においても癌の浸潤の場合と共通 のメカニズムが存在するものと思われる. 一方, 癌の転 移に関しては, 癌細胞の運動促進因子, 細胞接着因子, 癌細胞之宿主の免疫系之の相互作用, 組織に存在する増 殖因子や増殖阻害因子と癌細胞の相互作用なども関係す ると考えられている.

1) D. Moscatelli \& D. B. Rifkin : Biochim. Biophys. Acta, 948, 67 (1988).

2) S. Wilhelm, I. E. Collier, B. L. Marmer, A. Z. Eisen, G. A. Grant \& G. I. Goldberg : J. Biol. Chem., 264, 17213 (1989).

3) L. A. Liotta, C. N. Rao \& U.M. Wewer: Ann. Rev. Biochem., 55, 1037 (1986).

4) 宮崎 香, 真島恵介, 山下信彦, 紀平安則, 山下仁平, 堀 尾武一: 生物物理化学, 28, 1 (1984).

5) K. Miyazaki, Y.Ashida, Y. Kihira, K. Mashima, J. Yamashita \& T. Horio: J. Biochem., 102, 569 (1987).

6) L. M. Matrisian, P. Leroy, C. Ruhlmann, M.-C. Gesnel \& R. Breathnach : Mol. Cell. Biol., 6, 1679 (1986).

7) F. Umenishi, H. Yasumitsu, M. Umeda \& K. Miyazaki : $J$. Biochem., in press.

8) K. Miyazaki, Y.Hattori, F. Umenishi, H. Yasumitsu \& M. Umeda : Cancer Res., in press.

9) D. Muller, B. Quantin, M.-C. Gesnel, R. Millon-Collard, J. Abecassis \& R. Breathnach : Biochem. J., 253, 187 (1988).

10) G. I. Goldberg, B. L. Marmer, G. A. Grant, A. Z. Eisen, S. Wilhelm \& C. He : Proc. Natl. Acad. Sci. USA, 86, 8207 (1989).

(宮崎 香, 横浜市立大学木原生物学研究所) 


\section{窒素をシグナルとする光合成タンパク質遺伝子の制御}

\section{窒素栄養の状態によって光合成関連酵素タンパク質への窒素配分が变動}

植物葉に打いて大部分のタンパク質は光合成に関与し ている. $\mathrm{C}_{3}$ 草本類では, 葉の可溶性タンパク質の大半 はリブロース1,5-ビスホスフェートカルボキシラーゼ (Rubisco) であり, 不溶性タンパク質ではチラコイドに 局在する集光性クロロフィル結合タンパク質 (LHCP)が 大半を占める. 一方, トゥモロコシなどの $\mathrm{C}_{4}$ 植物葉で は, Rubisco に加克て $\mathrm{C}_{4}$ ジカルボン酸回路を構成する ホスホェノールピルビン酸カルボキシラーゼ (PEPC) とピルビン酸・リン酸ジキナーゼ (PPDK) が主要な可 溶性タンパク質である.これら炭酸固定系酵素は，量的 にも光合成速度を規定する要因であり, 窒素経済の上か らも重要な研究対象である.

植物に蚛臸素代謝の研究の歴史は長い，その研究 の多くは，窒素源をタンパク質や核酸など含窒素成分の 母材とみなし，もっぱら窒素の同化代謝の機序に焦点を おいたものであった，窒素の供給とタンパク質蓄積量と の関係についても，その供給に応じてタンパク質は一部 を除きすべて一様に增減するものと考兄られてきた．筆 者らは, トゥモロコシについて供給窒素と上記主要タン パク質の葉組織における蓄積量との関係を詳細に検討 し，この予測とは異なる興味深い結果を観察した，それ は, 細胞内の窒素栄養状態に依存してこれらタンパク質 の蓄積が著しく異なることであった ${ }^{(1)}$. Rubisco の蓄積 量の減少は窒素ストレス（窒素の供給を制限）下でも比 較的少ないのに対し, 他の 2 つタンパク質, とりわけ PEPC の変動は大きく，その蓄積量は窒素栄養状態に 際立って感応して減少した. その結果, Rubiscoのタン パ質での占有率は窒素供給量の增加につれ減少するの に対し，PEPCのそれは著しく增加した．これらの事実 は, これらタンパク質への窒素配分が細胞内の窒素栄養 状態によって制御されることを示唆している.

窒素は, 生物の生活を最も大きく規定する化学的な環 境要因のひとつである.上記の観察を契機に; 植物細胞 の窒素栄養状態に依存するタンパク質への窒素配分制御 のしくみの解析を試みることにした．通常，植物を対象
とする生化学的な研究の多くは, 葉組織全体を分析の対 象とすることが多い，ところが葉組織は，周知のよう に，齢や分化の度合いについてきわめてへテロな細胞の 集団である. したがって，観察すべきパラメータの変動 が希釈され，その幅が低下することがしばしばある。こ の点を踏ま光，上記の現象が増幅される細胞領域の探索 を行なっな結果, 窒素のこれらタンパク質への配分制御 が成熟中の光合成細胞で最も顕著であり，その変動は全 葉とは桁が異なり，大きく増幅されることが判明した。

この知見に基づき，筆者らは光合成的に成熟途上にあ る葉基部に着目し, 窒素ストレスからの回復の遷移過程 について解析を行なった．窒素ストレスからの回復につ れ, PEPC は急速に合成され, その蓄積は MRNA 蓄積 量の増加をともない劇的に増加した (2). この mRNAの 蓄積增加は一義的には転写活性の上昇によるもので, 核 による run on* 転写活性は窒素ストレスからの回復過 程で速やかに上昇し, 細胞の窒素栄養状態が回復するに つれ低下する．この間，PPDK の遺伝子の転写活性も PEPC と同様なパターンで推移するが, mRNA ならび にタンパク質の蓄積は PEPC ほどには増加しない。多 分, PPDK の窒素による発現は転写以外の段階, たと兄 ば翻訳や葉緑体への輸送過程でも制御されるのだろう.

これらの実験結果が意味するところは，PEPC 発現は 窒素によって制御されることであり，与充窒素源（硝 酸塩またはアンモニウムイオン) が直接または間接的に 遺伝子の on/off のシグナルとしてはたらくことを示する のである.制御を受ける遺伝子という点では異なるが， これと類似の現象はクラミドモナスに烼いても観察され ている(3). この緑藻では, LHCP が窒素栄養に応答し転 写段階で制御される。いずれの生物においても，窒素に 応答して優先的に発現制御をらける PEPC と LHCP が 光合成に付带的な役割を果たすものであり，極言すれば 光合成そのものには不可欠なタンパク質でないことは付 記されるべきことであろう。しかし，その半面，これら

*単離核を用いた in vitro での転写伸長反応 
のタンパク質が光合成の効率を高め, バイオマスの拡大 には欠かせない成分であることも忘れてはなるまい。

窒素をシグナルとし, 窒素利用系タンパク質の遺伝子 発現が制御されることは, 硝酸塩による硝酸還元酵素の 誘導として比較的古くから知られている. また，大腸菌 をはじめバクテリアでは, 窒素利用にかかわるグルタミ ン合成酵素 $(\mathrm{GS})$ をはじめニトロゲナーゼなどの一群の 酵素の遺伝子発現が，窒素をシグナルとして制御される ことが知られており，近年そのしくみが解明された ${ }^{(4)}$. その概略は，GS の活性調節タンパク質 ntr B が細胞内 の窒素栄養状態（具体的にはグルタミンとケトグルター ル酸の比）を感知し， ntrC のリン酸化/脱リン酸化を介 して，一連の酵素遺伝子の転写を制御するといらもので ある.ここに話題として取り上げた窒素によるタンパク 質の遺伝子発現制御は，その制御の対象が窒素利用系で はなく炭素同化や光エネルギー転換にかかわる光合成タ ンパク質の遺伝子であるという点で新たな興味を提起し ている.

窒素によるこれら光合成タンパク質遺伝子発現制御の 代謝的な意義はなにか？ 窒素ストレス下では光合成の 活性が低下し, 代わって糖の分解が促進されることが判 明している. このことは, 窒素ストレス下では光合成生 物はマスの拡大を抑制し, 制限された窒素の利用効率を 向上すべく, その同化または窒素化合物の分解と再同化 に必要な炭素骨格を提供する方向へと代謝が移行するこ
とを意味するのであろうか. 一方, PEPC やPPDK に おいては, それら遺伝子の発現が光をシグナルとして転 写レベルで制御されることがすでに明らかにされてい る.この過程は窒素の栄養状態に依存したものであり, これら遺伝子の転写は, 窒素ストレス下では, たとえ光 があっても行なわれない(5).このことは, これら酵素遺 伝子発現に至る過程で, 光と窒素シグナルの伝達が交差 または共役していることを示唆する. 窒素をシグナルと する遺伝子発現のしくみはシスートランスによる遺伝子 発現制御の面からも興味あるテーマである. また，植物 細胞が窒素栄養状態を検知するしくみを理解する上で も，挑戦すべき重要な研究課題である．これらの問題の 解決は，植物に和ける炭素と窒素代謝の具体的なかかわ りについて，新たな展開を与えることが期待される. ま た，窒素のタンパク質への配分を制御することによっ て, 代謝のデザイン, 換言すれば, 新たな機能をもつ植 物の育種へとつながることも夢の一つかもしれない.

1) T. Sugiyama, M. Mizuno \& M. Hayashi : Plant Physiol., 75, 665 (1984).

2) S. Bambang, K. Miyata, H. Nakamoto, H. Sasakawa \& T. Sugiyama : Plant Physiol., 92, 963 (1990).

3) F. G. Plumley \& G. W. Schmidt : Proc. Natl. Acad. Sci. USA, 86, 2678 (1989).

4) B. Magasanik: TIBS, 13, 475 (1988).

5) M. Yamazaki, A. Watanabe \& T. Sugiyama : Plant Cell Physiol., 27, 443 (1986).

(鈴木石根, 名古屋大学農学部農芸化学科)

\section{蛋白質の核局在化機構亡人工核移行シグナル プロリンクラスターと塩基性アミノ酸クラスターの組合せに活性}

細胞質内で合成された蛋白質は, 細胞内の構造体に正 確に輸送されてはじめて秩序のある働さをする。特に, ミトコンドリア, ゴルジ体, 粗面小胞体, リソゾーム, 核, 液胞 (さらに植物では葉緑体) など, 複雑なオルガ ネラを持っている真核生物では，どのようにして正確な 輸送が行なわれるのだろらか. この問題は, 蛋白質自身 が局在化の “めじるし”を持っているといら仮説の実証 を中心に進められてきた. まだ多くの未解決な問題が残 っているものの, 最近になって問題点はだいぶ整理され た(1).この“めじるし”を蛋白質の局在化シグナルと呼
び，核蛋白質の場合は核局在化シグナルまたは核移行シ グナルと呼ぶ.

ところで，核は，他のほとんどのオルガネラと違っ て，脂質二重膜で囲まれた閉じられた空間ではない。核 膜には，核孔（nuclear pore）と呼ばれる特殊な構造体 が存在していて, ナトリウム, カリウムなどのイオンや ATP などのような核酸前駆体は自由に通過してしまう. また, メッセンジャーRNA は蛋白質と結合した複合体 としてこの核孔を通って核から細胞質に送られること が明らかになっている.さらに，一部の下等真核生物を 
除いて, 高等生物の細胞では分裂時には核膜がこわれて しまう。それなら，細胞質から逆に蛋白質も核に簡単に 分散していってもよさそうである. 核に存在する蛋白質 は拡散によって核内に入り，DNA や核を構築する物質 などに吸着し蓄積することで，その局在化が説明できる とする説が漠然と支配してきたのも当然であった．

1970 年代の終わり頃から, 蛋白質の核移行にも特異 的な輸送が存在することを示唆する実験結果が徐々に現 われ始めたが，広く知られるには至らなかった。1984 年, SV 40 の T抗原の核局在化が蛋白質分子内に存在す る機能ドメインに支配されるといら発見(2)を大きな契 機として, 核局在化機構にも特異的な輸送経路のあるこ とが議論されるようになった．驚くべきことに，SV 40 の核への移行を支配する機能ドメインは Pro-Lys${ }^{128}$ Lys-Lys-Arg-Lys-Val という 配列をした短鎖のペプ チドであった.つづいて，このペプチドに相当する合成 DNA をßーガラクトシダーゼや，ピルビン酸キナーゼな ぞの遺伝子に結合させて, 動物細胞で発現させると, 本 来は細胞質にとどまるはずのこれらの酵素が核へ移行し てしまうことも明らかとなった. 当然, 他の核蛋白質に もこのような配列があるかどらかが調べられ，同年中に 酵母の Mat $\alpha 2$, インフルェンザウイルス核蛋白質など にも，同様の活性を示す配列が見いだされた，その後， 次々と核移行シグナルが同定され，いまではその数は 15 種類を越えている。

核移行シグナルは分泌シグナルやミトコンドリアへの 局在化ングナルと異なって, 蛋白鎖の $\mathrm{N}$ 端側に存在する とは限らず，C端側や蛋白質の内部の場合など様々であ る.また，これらのシグナルが核移行に伴って切り放さ れることもない，また，核蛋白質の核への局在化には， 核孔蛋白質との複合体形成のステップと核孔を経て核膜 を通過するステップとの 2 段階が存在し，核膜通過の段 階では ATP が必要なことが報告されている(3).

さて,これらのシグナルについての検討は一次構造上 の相同配列を発見することを目的として精力的に行なわ れたのだが，不思議なことに普通の意味でのホモロジー はまったく見いだされなかった ${ }^{(4)}$ はちちろん, シグナル の数だけ異なった核局在化の機構があると仮定すればよ いのだが，あまりにも不自然である，実は，論文に公表
されている以上に核移行シグナルの同定を試みているグ ループは多く, 大半はある長さ以下に切断すると活性が なくなることから，核移行シグナルの本質は立体構造で あると解釈して興味を失っているらしい(私信). 筆者ら も, 癌抑制遺伝子, p 53 の核移行シグナルの同定を試 み, 約 60 アミノ酸からなるぺプチドに絞り込んだ。こ の配列もさらに分断すればシグナル活性はなくなるが， この領域に存在している 2 つの塩基性アミノ酸に富む領 域とプロリンに富む領域を結合すると活性を回復するこ とを見いだした。

筆者らは,この発見が核移行シグナルとして要求され る条件を決める手がかりになると考え，人工的な配列で 核移行シグナルを作り出すことを計画した. 人エシグナ ルを設計するに先だって，筆者らは過去に同定された既 知核移行シグナルの再評価を行ならことにした．過去の シグナルは主に欠失変異法を用いて同定されているため に間違いが生じている可能性を否定できないからであ る.またこれらの配列はそれぞれに異なった系と手法 によって決定されて和り，比較のためには同一の方法で 調べ直す必要がある. 再評価の結果, :少なくとも, 酵 母の Mat $\alpha 2$ とインフルェンザウイルス核蛋白質の核 移行シグナルとして知られていた 2 種類の配列, LysIle-Pro-Ile-Lys と Ala-Ala-Phe-Glu-Asp-Leu-ArgVal-Leu-Ser は核移行シグナルとして機能しないことが 明らかとなった。この 2 種を例外として除去できれば, 核移行シグナルは，ほぼプロリン,リジン, アルギニン の 3 種類のアミノ酸の組合せと考えることができる.

そこで, プロリンと塩基性アミノ酸の組合せによるま ったく人工的な核移行シグナルの設計を試みた．様々な 組合せの配列を有する $\beta$-ガラクトシダーゼの融合蛋白 質を動物細胞で発現するプラスミドを構築し, その細胞 内分布を調べると，リジンあるいはアルギニンのみを長 くしたペプチドも，プロリンのみからなるペプチドも核 移行シグナルとして機能しなかったが，プロリンクラス ターと塩基性アミノ酸クラスターを組合せたペプチドは 核移行シグナルとなることが明らかとなった。ささらに， プロリンクラスターとリジンクラスターの順序を入れ換 えても, 各クラスター間の距離を変化させても, 核移行 シグナルとしての活性を有していた. この実験は, 蛋白 
質上にプロリンクラスターと塩基性アミノ酸クラスター が存在していれば，卡の蛋白質は核へ送られらることを 示している.

確かに，いくつもの転写因子などや核蛋白質にこのモ チーフは存在しているが, 過去に決定された核移行シグ ナルには必ずしもプロリンクラスター構造は見いだせな い. しかし, プロリンクラスター様構造はこれらの蛋白 質の別の場所に存在しており，何らかの理由で必要条件 のみが核移行シグナルとして同定されたのかもしれな い.人工核移行シグナルの設計を試みることから見いだ
されたプロリンクラスターの役割は, 案外蛋白質の核局 在化機構を明らかにするきっかけとなるかもしれない.

1) B. Alberts, D. Bray, J. Lewiis, M. Raff, K. Roberts \& J. D. Watson : in "Molecular Biology of the Cell, 2 nd eds.”, Garland, New York, 1989 ; 1990 年秋, 教育社よ り日本語版出版予定.

2) D. Kalderon, W.D. Richardson, A. F. Markham \& A. E. Smith : Nature, 311, 33 (1984).

3) D. D. Newmeyer \& D. J. Forbes : Cell, 52, 641 (1988); W. D. Richardson et al.: Cell, 52, 655 (1988).

4) B. Roberts : Biochim. Biophys. Acta, 1008, 263 (1988). (田中畺人, 三菱化成生命科学研究所)

\section{ハマナス葉中のカロタンパーオキシド 植物防御機權のーモモデルとして}

北海道を 含む北日本の海浜域に 自生するハマナス (Rosa rugosa Thunb.)は,いわゆる園芸バラで問題とさ れる幾つかの病害虫に対して強い抵抗性を有するため, その園芸的価值を特に欧米で高く評価された経緯を持 つ. しかし，この病虫害抵抗性因子の分子レベルでの研 究は, Mashchenko らが葉中ュレステロールの増減を抵 抗性と関連づけたもの (1987 年)(1) があるに過ざない。

筆者らは，機栈的傷害をうけた八マナス葉水抽出物か ら多量の抗菌活性成分を見いだしこれを1,5ーパーオ キシド架橋を持ったカロタン型セスキテルペンアルデヒ ド rugosalA (1) と同定した ${ }^{(2)}$.さらに, この内在性抗 菌性成分の関連化合物としてハマナス葉中から 1 亿対応 するカルボン酸 rugosic acid A (2) 预よび1の前駆体 carota-1, 4-dienaldehyde（3）を得た ${ }^{(2,3)}$ 。これらは季 節的増減はあるものの，開花期前後にはそれぞれ 100 $\mathrm{mg} / \mathrm{kg}$ fr. wt. 以上, 2 に至っては最高時で $700 \mathrm{mg} / \mathrm{kg}$ もの高濃度で含まれていた，低分子天然パーオキシドと

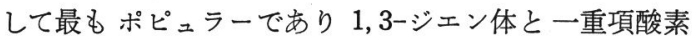

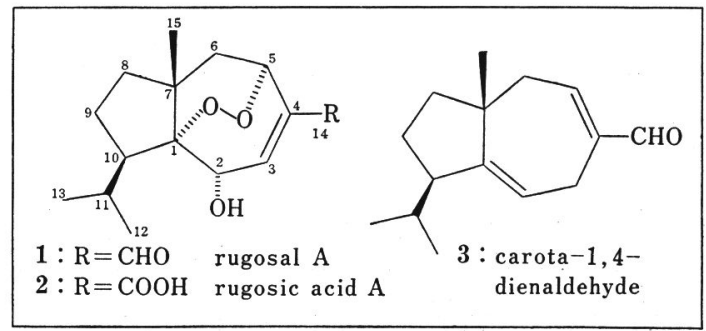

間の Diels-Alder 反応によって生成する 1,4-エンドパ ーオキシド類（たとえば ascaridol など）と違って，化 合物 1 のパーオキシド架橋形成は，エキソパーオキシド ラジカル体を中間体にとる不飽和脂肪酸類の過酸化物生 成のそれに近い。

前駆体 3 は空気中で不安定で, 速やかに 1, 2 を含め た幾つかのパーオキシド化合物へ酸化される，その自動 酸化経路については，C-2-OOH 中間体を得たことか ら，C-3 位の活性メチレンからの水素ラジカル引き抜き を引金とした三重項酸素二分子付加ラジカル反応を提出 した(4). 一方, 八マナス葉組織中に和けるカロタンパー オキシドは，葉の成長熟成に伴う急激な消長が 見られ る. rugosic acid A (2) が1の初期代謝産物として八 マナス葉中での最大プールになっている事実は，2 の抗 菌活性が完全に消失していることに合理的な意味あいを 持たせているように思える.

このカロタンパーオキシド類が一時期，八マナス葉中 に大量に蓄積するのに対し, 生体膜構成成分である不飽 和脂質の過酸化物は，植物を含めた生体内組織内で多量 に蓄積することはない，なぜならこういった過酸化脂 質類は非常に不安定である上，生体組織中で速やかに代 謝分解されるからである.このカロタンパーオキシドの 蓄積に関しては，これらが過酸化脂質に比べ，パーオキ シド酸素原子ーアリル水酸基間の分子内水素結合によっ てきわめて安定であることが大きな要因と考えられる. 
また,この過酸化物の量から見て, ハマナス葉組織はと りわけ強い酸化的条件下にあると考觉ることもできる. しかしながら，ハマナス葉が $\beta$ ーカロチンなど抗酸化因 子に富んでいること, 1,2 とも葉の老化進行に伴ってド ラスティックに消失してゆくことから， ハマナス自身こ れらの生成や代謝を酵素的に制御していると思われる. では, 一時期とはいえ, なぜカロタンパーオキシドがこ のように異常なほど蓄積されるのだろうか？ 現在， 八 マナス由来のセスキテルペンパーオキシドの組織中での 機能的役割は, 主に病原菌などの侵入に対する防御因子 としてのものであると考えている.

Rugosal A（1）の抗菌活性は各種方法で詳しく検討 し, 本化合物が一部の糸状菌, 酵母あるいはグラム陽性 菌にある程度, またイネイモチ病菌に対しては EDDP* に匹敵するほど阻害的であることがわかった。しかし， ハマナスが際立った抵抗性を示すといわれているバラ黒 斑病菌に対する抗菌活性試験についてはまだ行なわれて おらず，1をハマナスの病害虫抵抗性因子と断言するに は至っていない、ただ，ハマナス交配種，変種を除き， 我が国に自生する主な野生バラ扎よびいくつかの園芸バ ラからはカロタン類がをったく検出されないので, カロ タンパーオキシドをハマナス特有の抗菌性因子と見なす ことはできよう.カロタン型セスキテルペンは, 高等植 物に和汁る分布がセリ科および少数のキク科に限られて いるが，例外的にバラ科バラ属ハマナス系統のみがこの ような成分を含有しているのはなんとも不可解である.

本抗菌性化合物の組織内での分布，および傷害部から の浸出状況もまた， 1 が防御因子として機能しているこ とを示している. ハマナス由来カロタンパーオキシド は，その分布がほとんど 、マナス葉裏面のトリコーム (突起様構造) に限られていることがわかりつつある. タバコ, ポテトなどでトリュームが生体防御器官として 機能していることが示されているが(5)， 八マナス葉トリ コームにもこれに類する働きがあるのであるら.

一方, 浸出時に拈ける 1 の見かけ上の集積は, より重 要な意味を含んでいる. 葉全体における傷害部位はそれ ほど大きくはなく，さらに rugosal A（1）が著しく難 溶性であるにもかかわらず, 葉傷害部から水相への全浸

* O-ethyl diphenyl phosphorodithiolate
出物中に占める 1 の割合が非常に高いといら事実は, 傷 害部への 1 の積極的な蓄積を意味する，実際, 傷害葉を 浸漬した水層の酢酸エチル転溶部中性画分中の 1 の含有 率は約 $15 \%$ にもなった. また, 特に開花期以前の葉で は注添内在全量に相当するカロタンパーオキシドが遊離 し，その残椬からはそれらを臣とえど検出できなかった. これらのことは，1が実際に被傷害部で糸状菌などの感 染に詨する防御因子となっている可能性を示している.

これをさらに詳しく検証するために簡単な予備実験を 試みた。 新鮮なハマナスの葉片に一定の長さの切傷を与 え, これを 1 傷害ニニットとした. これから傷害量と 1,2 遊離量との間に比例関係が成り立つかどうかを調 ベたのだが，この予備実験の結果を見る限り，ハマナス 葉からのパーオキシドの遊離は内在性成分の単なる拡散 によるとは思觉なかった.つまり，カロタンパーオキシ ドの 24 時間後の遊離量は傷害量ではなく健全葉重量に 依存し, しか子葉片全体の $30 \%$ に当たる 1 がたった 1 ユニットの傷害により浸出したのである. 追試の必要性 はあるものの，この結果から筆者は葉の健全組織が傷害 部からの刺激伝達により何らかの生理的変化を起こし, 続いて傷害部への 1 の移送が起こるのではないかと考壳 ている. 現在, より綿密な検証に取りかかっており，ど のような仕組みでこの抗菌性成分の傷害葉からの積極的 浸出が起こるのかをぜひ明らかにしたいと考えている.

このハマナス抗菌活性成分の生成例は, 植物における パーオキシド生成が非常に活発であり, 生活環による代 謝調節を受けていることを意味している，これまで，高 等植物について内生の $\mathrm{H}_{2} \mathrm{O}_{2}$ 量の測定と生成機構につい て行なわれた研究がいくつかあるが(6)，抗菌作用を示す 有機化合物については本研究が最初である.さらに, 1 の浸出は, 健全組織細胞での傷害認識といら高等植物に おける情報伝達の一表現と考它られるため，この分野を 研究するモデルになりらるかもしれない. 本化合物の構 造決定については，各投稿論文を参照していただきた い, また, 本稿内容については, 多方面からの御批判を 仰ぎたいと思っている.

1) N. E. Mashchenko, N.E.Mash, P.K. Kintaya, S. N. Semina, N. N. Balashova \& S. A. Shvets : Chem. Abstr., 109, 187501 (1988).

2) Y. Hashidoko, S. Tahara \& J. Mizutani : Phytochemistry, 
28, 425 (1989).

3) Y. Hashidoko, S. Tahara \& J. Mizutani : Phytochemistry, 29, 867 (1990).

4) Y.Hashidoko, S. Tahara \& J.Mizutani : J.Chem. Soc. Perkin Trans. I, 投稿中.
5) R.W. Gibson \& J. A. Pickett: Nature, 302, 608 (1983).

6) A. Ishida, K. Ookubo \& K. Ono: Plant Cell Physiol., 28, 723 (1987).

（橋床泰之，北海道大学農学部）

\section{ビアラホス生産菌のグルタミン合成酵素遺伝子}

\section{原核生物における“真核型”醭素遺伝子の起源は?}

国立遺伝学研究所の舘野義男さんを最初に訪ねたのは 昨年の夏であった．筆者は原核生物である放線菌が真核 型のグルタミンシンセターゼ (GS) 遺伝子を持っている 事実を雑誌に投稿しようとしていた，舘野さんを訪ねた 目的は, 各種 GS の分子系統樹 (phylogenetic tree) を 作成して投稿内容を充実させようと思ったからである.

最初, 少数の GS のアミノ酸配列を基に分子系統樹を 作成した，彼はその采統樹に少なからぬ興味を示した。 その系統樹が，GS 蛋白の起源がきわめて古いことを暗 示していたからであった. そして, もっとたくさんの GS で系統樹を作れば，それによって GS の進化をさら に詳しく知ることができるに違いないと考えた，それか ら舘野さんの指導で分子系統樹作りが始まった. たくさ んの GS のアミノ酸配列を並べて最適なマッチングを捜 し出す作業に休日の大半を費やした.

そもそも, この研究を始めた発端は, GS 阻害剤であ るビアラホス（除草剂としてハービーエースという商品 名で明治製菓より発売中) を生産する放線菌 (Streptomyces hygroscopicus SF 1293) の GS が量的・質的に ぞのような性格を持っているのだろらかといら疑問から であった。 また, 生産性との関連で, 応用面からも解明 する必要のある問題であった. 量的な面では, この菌株 の GS 活性はビアラホス発酵生産過程で常に高く維持さ れていることがわかった ${ }^{(1)}$. 恐らく，そうすることによ って自らが作り出した GS 阻害物の攻撃に耐えていると 考えられる. 事実, 多コピープラスミドに GS 遺伝子を 組み込んで宿主の GS 発現量を増強すると, ビアラホス 耐性が発現することが証明されている(2,3).

ところが，研究の過程でさらに興味深い事実が明らか になった. すなわら,この菌株は蛋白構造・機能の両面

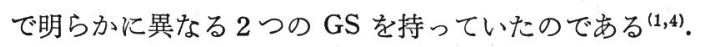
GSI-Sh と名づけた一方の GS は分子量 55,000 dalton
で， $\mathrm{N}$ 末端のアミノ酸配列は他の放線菌 Streptomyces coelicolor の GS (GSI-Sc) とほとんど同じであった. これは明らか原核生物型の GS (GSI) であった。もら 一方の GS II-Sh は遺伝子クローニングによって初めて 発見されたのであるが, 分子量 37,400 dalton, $50^{\circ} \mathrm{C}$ でも不安定で，ビアラホスによる阻害に対して GS I-Sh よりも感受性が低く, 塩基配列から推定したアミノ酸配 列は GSI-Sh とまったく異なっていた。 それはむしろ 真核生物の GS (GS II) に類似していた。しかも驚いた ことに, GS II-Sh をコードする遺伝子 $(g \ln \mathrm{B}-\mathrm{Sh})$ と 類似の遺伝子配列が他のほとんどすべての放線菌に認め られたのである.

従来，真核生物と原核生物から見いだされる GS は, 構造的に互いに大きく異なっているため，それらはそれ ぞれの生物に特有のものであると考えられてきた。たと えば，分子量については原核，真核生物の GS はそれぞ れ 47〜 53 kd, 37〜 42 kd で, 原核生物の GS のほらが 平均 $13 \mathrm{kd}$ 程度大きい.これは, 真核型 GS が原核型 GS のC末端側 70〜90 アミノ酸に相当する部分を欠い ているためである.この部分にはアデニリレーションサ イトが存在し，原核型 GS の活性制御にきわめて重要な 役割を持っている. また，アミノ酸配列に関しても大き な違いが認められる.

ところが，原核生物である根粒菌 (Rhizobium) や癌 腫菌 (Agrobacterium) は両方のタイプの GS 遺伝子 $(g \ln \mathrm{A}, \mathrm{B})$ を持っていることが知られ ${ }^{(5)}$ ，真核型である $g \ln \mathrm{B}$ は宿主である植物からの転移によって生じたとす る考えが支持されるよらになった．しかし筆者らが，植 物と共生・寄生関係を持たない放線菌にも $g \ln \mathrm{B}$ 遺伝子 が存在することを明らかにするに及び，原核生物におけ る $g \ln \mathrm{B}$ の存在を転移のみによって説明することは困難 となった. また, Shatters と Kahn は, 根粒菌の GS II 


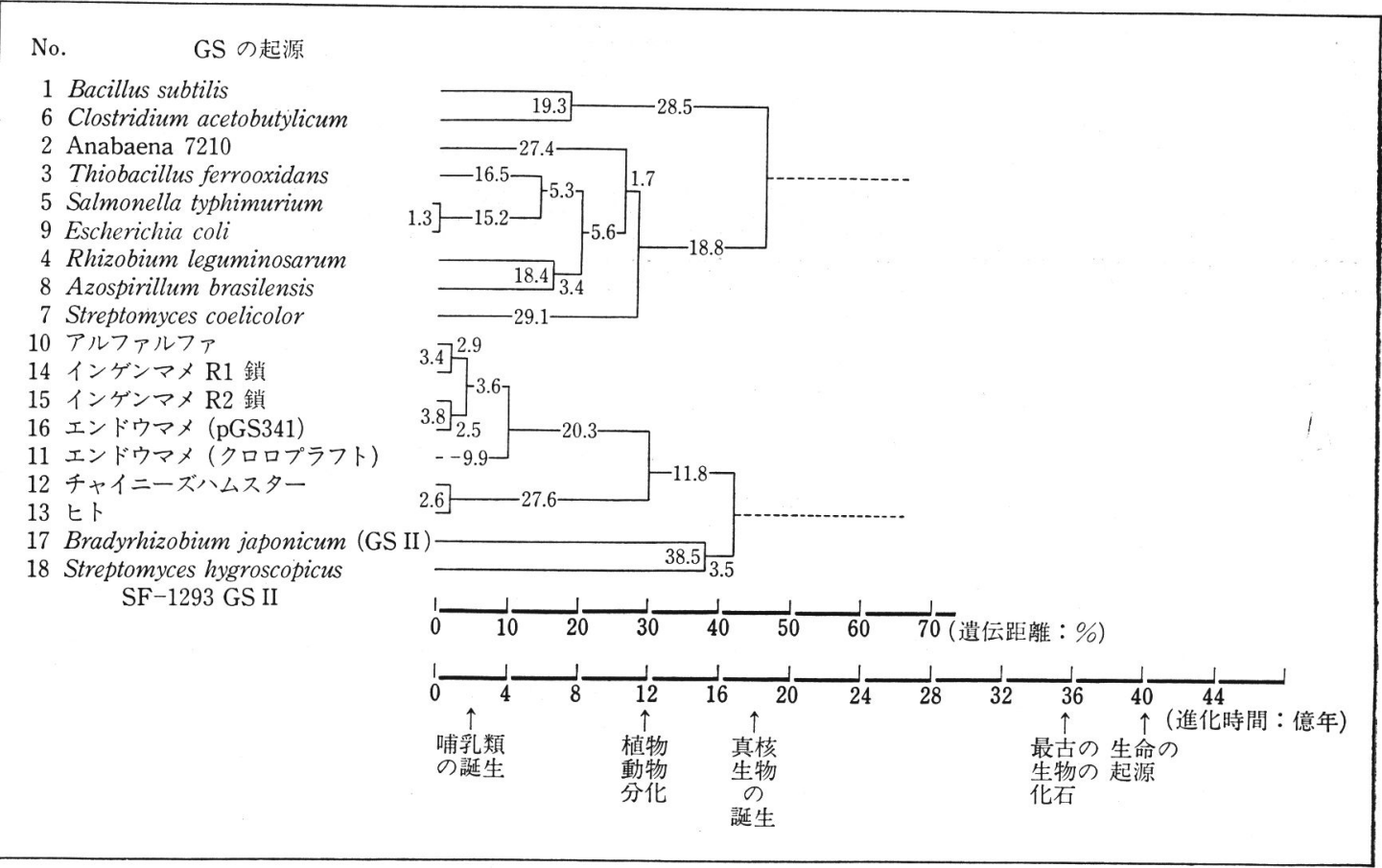

グルタミンシンセターゼの分子系統樹 (UPGMA 法)

まず GS アミノ酸配列のアラインメントを行ない，全 GS に共通な領域を抽出する. この領域について各 GS 相互で一致しないア ミノ酸の割合（％) を求め，遺伝距離のマトリックスを作成する．次に，「蛋白質の進化に拉けるアミノ酸置換は，時間に対して一定 である(7)」という木村資生博士の中立説に基づき, UPGMA 法 ${ }^{(8,9)}$ によって系統樹を作成した。

の祖先が植物の起源よりも古いことから，転移説に疑問 を投げかけていた(6).

この疑問に対し，筆者らの作成した GS の分子系統樹 が 2 つの重要な答えを示した. 図は GS II-Sh (No. 18) を含む 18 種類の GS の分子系統樹を示している. 横軸 はアミノ酸の座当りの置換率（\%) で表わした遺伝距離 と進化時間（億年）を表わしている. 遺伝距離と進化時 間との対応づけは，植物と動物の分岐時間を 12 億年と して行なった.

まず第 1 の答えは, 根粒菌の GS II や GS II-Sh が植 物から転移したという説は否定されることである。なぜ なら，植物と動物の共通の祖先は 12 億年前であり， 根粒菌の GS II (Bradyrhizobium japonicum II) と GS II-Sh との共通の祖先はそれよりもさらに古く 14 億 年くらい前と推定されるからである.

2 番目の答えは，真核生物と原核生物とが分化する以 前 (18 億年以前) にすでに GS の分化が起こったこと である. 現在知られている最も古い生物の化石は 36 億
年前のものと言われているが, 36 億年前（あるいはそれ 以前）から 18 億年前の間に GS の祖先遺伝子が遺伝子 重複を起こし, 現在の真核型・原核型 GS の基になった と考えられる. 放線菌のように両方の GS 遺伝子を有す る生物の存在がそれを裏付けているように思われる.

1) Y. Kumada, E. Takano \&'K. Nagaoka : J. Ferment. Bioeng., 70, No. 1 (1990).

2) Y. Kumada, H. Anzai, E. Takano, T.Murakami, O. Hara, R. Itho, S. Imai, A. Sato \& K. Nagaoka : J. Antibiotics, 41, 1838 (1988).

3) S. DasSarma, E. Tischer \& H. Goodman : Science, 232, 1242 (1986).

4) Y. Kumada, E. Takano, K. Nagaoka \& C. Thompson : J. Bacteriol., in press (1990).

5) T. Carlson \& B. Chelm: Nature, 322, 568 (1986).

6) R. Shatters \& M. Kahn: J. Mol. Evol., 29, 422 (1989).

7) M. Kimura: "The Neutral Theory of Molecular Evolution", Cambridge Univ. Press, 1983.

8) P. H. A. Sneath \& R. R. Sokal : "Numerical Taxonomy", Freeman, San Francisco, 1973.

9) M. Nei : "Molecular Population Genetics and Evolution", North-Holland, 1975.

（熊田庸一, 明治製菓(株)薬品開発部) 


\section{植物木ルモン様活性を示す植物毒素}

\section{雑草シバムギの病原菌から単離されたgigantenoneの生理作用}

植物病原菌が生産する天然生理活性物質は, その構造 に対する化学的興味もさることながら, 植物に対する活 性の重要性からも注目されている(1). これらの化学物質 の活性は, 病原性に着目すると, 毒性を発現する植物毒 素之病原菌の病徵発現との関係が焦点となる ${ }^{(2)}$ が, 植物 に対して生長抑制や生長促進作用を示す生物活性るまた 化合物自身が持つ活性として注目される。たとえば，放 線菌から単離された kaimonolide $\mathrm{A}^{\prime}$ は $0.2 \mathrm{ppm}$ でレ タスの根の伸長を $50 \%$ 阻害する(3). また, 植物病原菌 の Neocosmospora vasinfecta から得られた neovasinin は $10 \mathrm{ppm}$ の濃度でコントロールの 6 倍の発根促進作用 を示す ${ }^{(4)}$. このような植物病原菌由来の植物生長調節物 質のなかで最もよく知られている例はジベレリンであろ う.ここ数年, 再び稲作に被害をもたらしている稲馬鹿 苗病菌 Gibberella fujikuroi の培養液から単離されたジ ベレリンは, 高等植物中に広く分布する植物ホルモンで あることは周知のことである(5).

このよらに, 微生物の生産する物質の中には, 植物の 発芽, 発根, 成育を促進するような化合物が知られてい る.この例をいくつか挙げてみよう.

(1) Helminthosporol 関連化合物：コムギ斑点病 菌 (Cochliobolus sativus) がイネ幼苗を著しく伸長させ ることから培養液を検索したところ, 活性本体としてへ ルミントスポロール (helminthosporol) が単離された(6). ヘルミントスポロールおよびその類縁体の helminthospororic acid は $30 \mathrm{ppm}$ の濃度で,イネの第二幼鞘を 2 倍に伸長させた(7)、化学構造的にジベレリンの C, D 環 に類似する点は大変興味深いことである.金らは, へル ミントスポロールの官能基を変換した誘導体を合成して 生理活性と構造との関連を調べている(8). また，cissativendiol はさらに高い植物生長促進効果を示した ${ }^{(9)}$.

(2) Sclerin 関連化合物：Sclerotinia libertinia の菌体抽出物から単離された sclerin は, イネ幼植物 などの発芽促進や著しい伸長効果を示す．類似物質の sclerotinin む $5 \mathrm{ppm}$ の濃度でイネ幼植物の伸長を促進
した(10).

(3) Fusicoccin 類縁体： fusicoccin は最初 Fusicoccum amygdali から植物毒素 (phytotoxin) として単 離されたが, 後に植物生長促進物質として研究されるよ らになった. fusicoccin には 44 種の類縁体が存在する が, 植物毒性・生長促進効果とも fusicoccin が最も強 い活性を示す(11).

(4) Cotylenin 類縁体: Cladosporium の一種か ら得られた cotylenin は fusicoccin と類似の化学構造を 持っており, $1 \mathrm{ppm}$ の濃度でハクサイなどの子葉の伸長 を促進する(12).

（5）Graphinon (ovalicin) 関連化合物：カビの一 種 Graphium の培養液から単離された graphinone は, $10 \sim 50 \mathrm{ppm}$ で光発芽種子のレタスの発芽を暗所で誘起 する(13).

(6) Pestalotin 関連化合物: pestalotin は Pestalotia cryptomeriaecola から単離され, ジベレリンの伸 長効果を増強する(14).

これらの例に加えて, Drechslera gigantea の培養液か ら単離されたセスキテルペン類が植物に対してきわめて 興味ある生理活性を示すことが最近明らかになった(15). D. gigantea は雑草のシバムギ (Agropyron repens) から 単離された植物病原菌で, 種々の雑草〔メヒシバ (Digitaria spp.), ギョウギシバ (Cynodon dactylon), シバ ムギ】に緑色の病斑を形成する。この症状はしばしば, グリーン・アイランド (green island) 効果として知ら れており, 植物ホルモンのサイトカイニンに典型的に観 られるものである.

ジベレリンの例でも知られているように, 植物病原菌 から植物ホルモンあるいは, 植物ホルモン的な生理活性 を示す物質が得られる可能性がある. D. gigantea の例 でも, 生産物質による病状と植物ホルモン様活性の関連 が調べられている。

生産菌の培養液あるいは, 精製に伴う各区分の 溶液 (100〜1000 ppm) を $5 \mu 1$ ほど葉片にシリンジでつけ, 


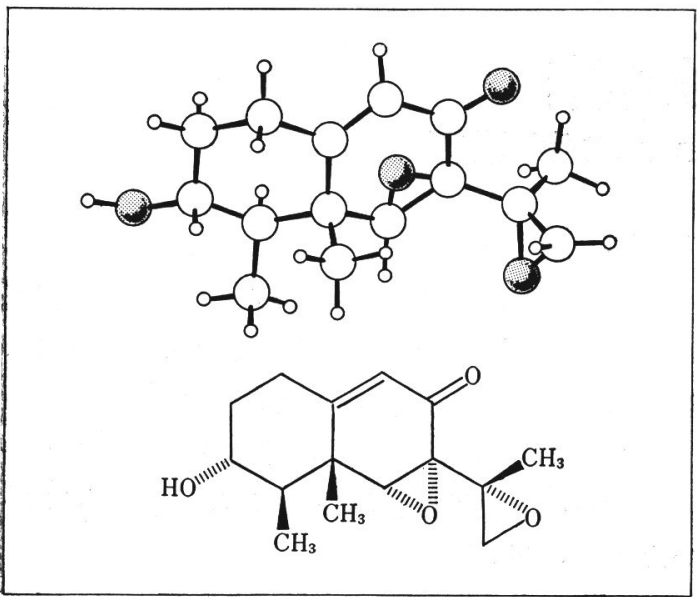

図 1. Gigantenone の化学構造

24 72 時間後に病斑を観る試験方法で, 13 種の類縁体 が単離された，各々の物質の化学構造は NMR（核磁気 共鳴スペクトル), 高分解能質量分析計などにより決定 された．基本的な骨格はデカリン環を持つセスキテルペ ンでエレモフィラン型 (eremophilane) と総称されるも のである. その中には，植物毒素として知られている phomenone, phaseolinone などが含まれている(16).

13 種の類縁体のうち gigantenone の化学構造を例に 述べると, 分子式が $\mathrm{C}_{15} \mathrm{H}_{20} \mathrm{O}_{4}$ で, 融点が $140^{\circ} \mathrm{C}$ の白色 針状結晶で, 旋光度 $\left([\alpha]_{\mathrm{D}}\right)$ は $+160^{\circ}$ であった. プロト ン NMR では 3 本のメチル基が観測され，そのうち 2 本が 3 級炭素に結合し $\left(\delta_{\mathrm{H}} 1.59,1.10 \mathrm{ppm}\right)$, 残りの 1 本が 2 級炭素に結合していた $\left(\delta_{\mathrm{H}} 1.27 \mathrm{ppm}\right)$. その他, 酸素の置換基を持つ 6 本の炭素洁合したプロトンのう ち 1 本はシングレット $\left(\delta_{\mathrm{H}} 3.65 \mathrm{ppm}\right), 1$ 本がメチレン 基 $\left(\delta_{\mathrm{H}} 2.84,2.60 \mathrm{ppm}\right), 1$ 本がマルチプレット（ $\delta_{\mathrm{H}}$ $3.61 \mathrm{ppm}$ ) であった。これは，1個の水酸基と 2 組のエ ポキンド基の存在を示している.これらのスペクトルの 特徵からェレモフィラン構造が推定されたが, 立体構造 はX線結晶解析によって決定し, 絶対構造は AO 1 の旋 光度 $\left(+214^{\circ}\right)$ の比較から決定された ${ }^{(17)}$. gigantenone の化学構造とX線結晶解析の結果を基にして, コンピュ ーターで描いた投影図を図1に示した。

Gigantenone の対植物活性を点滴法により種々の植物 の葉を使用して観察した．葉片あたり $18 \mathrm{nmol}$ を兄た ところ, 14 種の単子葉植物のうち 12 種に $1 \sim 2$ 日後に

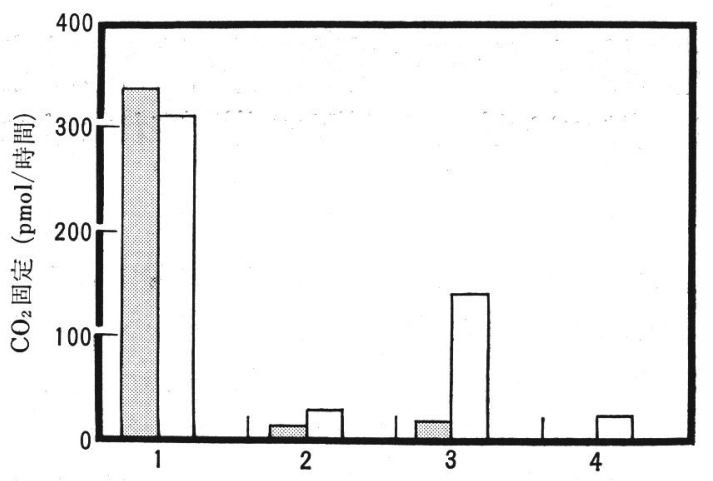

図 2-Gigantenone の生物活性

噔奴 : 暗条件下, $\square:$ 光照射下, 1 : 新鮮葉 (コントロール), $2:$ 被験葉（コントロール）, 3: グリーン・アイランド部, $4:$ 枯 死部

グリーン・アイランドを形成した。すなわち，トウモロ コシ (Zea mays), サトウキビ“51 NG 100” (Saccharum officinarum), オートムギ (Avena sativa), カラス ムギ (A.fatua), シバムギ (A.repens), カモジグサ類 (A. intermedium), ギョウギシバ (C. dactylon), メヒシ バ類 (Digitaria sanguinalis), ジョンソングラス (Sorghum halepense), ヘマスゲ類 (Cyperus esculentus), ム ラサキオモト (Rhoeo discolor) などである、サトゥキ ビ “H 50-7209” (Saccharum officinarum) とモロコシ (Sorghum vulgare) ではグリーン・アイランドを形成し た. 一方, 双子葉類についてはネクロシスや白化が生じ た。

グリーン・アイランド効果は多くの植物病原菌の一つ の病徴とみられているが，それがはたしてサイトカイニ ンのような植物ホルモンを生産することによるのか， あ るいは菌体の生産物が持つ生物活性によるものかは, 実 はあまりよくわかっていない、そこで，このグリーン・ アイランド効果が一体何に起因するのかを知るために, 最も感受性が高かったオートムギを用いて次のような実 験を行なってみた、試験葉の表面に検体を含む溶液をつ け, 光照射下に $25 \sim 27^{\circ} \mathrm{C}, 3$ 日間おいた. 一定の面積を 切り取り, ジメチルスルホキシドでクロロフィルを抽出 し，665 nm の波長で測定したところ，gigantenone を 用いた葉では，クロロフィルが激減していたが, 同濃度 のカイネチンではクロロフィルがコントロールよりも高 いレベルで保持されていた（図2）。この傾向は，試験溶 
液に葉を浮かべる方法で特に顕著であった。 したがって， いずれの試験葉も緑色をしていたが，クロロフィル含量 は異なっていた。ささらに, 試験葉から抽出したクロロフ ィルを用いて炭酸固定能を調べたところ，緑色の部分で は, 新鮮葉の約半分の固定能を示したが，枯死した部分 では当然のよらにほとんど消隇していた。

Gigantenone と植物ホルモン活性の関連を確かめるた めに緑豆の発根促進能を調べると $10^{-5} \mathrm{M}$ の濃度では indole-3-butyric acid (IBA) とほぽ同程度であった. ま た，種々の植物の組織培養に用いてみたところ, ックパ ネアサガオ (Petunia hybrida) の発根を10 日間で促進 し，アスパラガス (Asparagus officinalis) の根の伸長を 促進した。 これらの促進作用は $1.8 \mu \mathrm{M}$ の濃度で顕著で あったが，高濃度では逆に阻害的であった。このような 活性は, 13 種の類縁体の中では gigantenone が最も強 く,さらに側鎖のエポキシドが非天然型のエピマーは, 天然型より弱い活性を示した ${ }^{(18)}$.

ここで述べたよらに，植物病原菌から単離された化合 物が，植物ホルモンが示すような有用な，あるいは有効 な利用法を検討することが重要になっている，その理由 の一つには, 既存の植物ホルモンに代わることはないに しても，作用の類似性や関連性に注目することにより， 植物ホルモンの作用機構の解明に役立てることがでさる かも知れないからである. ジベレリンとへルミントスポ ロールの関係がその好例であろうし, gigantenone もま たサイトカイニンとの関係に興味が持たれる.

1) 坂村貞雄 : 化学と生物, 23, 289 (1985).

2) A. Granti, R.D.Durbin \& A. Ballio (eds.): "Phytotoxins and Plant Pathogenesis", Springer-Verlag, 1989, p. 123.

3) A. Hirota, H. Okada, T. Kanza, M. Nakayama, A. Hirota \& A. Isogai : Agric. Biol. Chem., 53, 2831 (1989).

4) H. Nakajima, K. Nishimura, T. Hamasaki, Y. Kimura \& S. Udagawa : Agric. Biol. Chem., 51, 2831 (1989).

5) N. Takahashi (ed.) : "Chemistry of Plant Hormones", CRC Press, 1986, p. 59.

6) S. Tamura, A. Sakurai, K. Kainuma \&M. Takai : Agric. Biol. Chem., 29, 216 (1965).

7) A. Sakurai \& S. Tamura : Agric. Biol. Chem., 29, 407 (1965).

8）金範泰，金建佑，山根久和，菅原二三男，吉田茂男，高橋 信孝：農化誌, 64, 403 (1990).

9) M. Nukina, H. Hattori \& S. Marumo: J. Am. Chem. Soc., 97, 2542 (1975).

10) Y.Satomura \& A. Sato: Agric. Biol. Chem., 29, 337
(1965).

11) A. Ballio: "Toxins in Plant Disease", Academic Press, 1981 , p. 395.

12) 佐々武史：農化誌, 49, 35 (1975).

13) T. Sassa, H. Aoki, Y. Ogawa \& K. Munakata : Nature, 222, 773 (1969).

14) Y.Mimura, K. Katagiri \& S. Tamura: Tetrahedron Lett., 1971, 3137.

15) D. Kenfield, G. Bunkers, Y.-H. Wu, G. Strobel, Y. Hallock \& J. Clardy : Experientia, 45, 900 (1989).

16) A. Stoessl : "Toxins in Plant Disease", Academic Press, 1981, p. 110.

17) S. Tanaka, K. Wada, S. Marumo \& H. Hattori : Tetrahedron Lett., 25, 5907 (1984).

18）蔵田等司, 北原 武, 森 謙治: 農化誌, 63, 524 (1989).

（菅原二三男, 理化学研究所）
教官公募

\section{名古屋大学農学部養虫学助教授}

募集人員：名古屋大学農学部養亘学助教授 1 名 分 野: 蜚または他の昆虫の病理学において優れた研究業績 をあげつつあり，これを基礎として養䖽学の発展お よび昆虫病原徽生物・昆虫ウイルスの開発, 利用に 貢献し, 教育に熱意のある方.

応募締切: 平成 2 年 7 月 14 日（土）

提出書類 : 履歴書, 研究業績リスト, 論文別刷など

応募方法 : 詳細は下記にお問い合わせ下さい。

問合せ先 : =464-01 名古屋市千種区不老町

名古屋大学農学部盖亘学助教授選考委員会

委員長 山下興亜 